音声言語医学 $55 ： 123-129,2014$

\title{
語流暢性課題に扔ける質的分析の試み
}

一通常成人群を対象に——

浜田 智哉1-3) 黒川 容輔 ${ }^{11}$

要 約：日本語話者での動物意味カテゴリー語想起課題について質的評価法の作成および妥 当性と特徵の検討を試みた。研究 1 では語想起課題中の“まとまり”を抽出し可視化すること を目的とした. 方法としては想起された語同士の共起比率を算出し, クラスター分析を行った. 研究 2 では語想起課題中の “まとまり” と意味的類似性判断課題の結果との整合性の検証を目 的とした，方法としては意味的類似性判断課題の結果からクラスター分析図を作成し，研究 1 の結果と比較した．研究 3 ではわれわれの分析方法の特徴を検討することを目的とした．方法 としては研究 1,2 で得られた結果に主成分分析を行い, 抽出される属性を比較した。研究 1,2 , 3 の結果, 語想起課題中にはペット, 野生肉食獣, 野生大型草食獣, 干支, 里山動物, サル科 動物，海洋ほ乳類などのまとまりが抽出された。また，われわれの分析方法では意味的類似性 判断課題に比べ, 多くの属性を抽出できた.

索引用語：言語流暢性課題, 質的分析, 共起, 3 つ組, 意味的類似性

\section{A Qualitative Analysis of Verbal Fluency Tasks in Normal Japanese Adults}

Tomoya Hamada ${ }^{1-3)}$ and Yousuke Kurokawa ${ }^{1)}$

\begin{abstract}
We developed a qualitative analysis method for verbal fluency tasks in Japanese natives. In this paper, we discuss the validity and characteristics of our qualitative analysis. The purpose of study 1 was to detect and visualize clusters seen during animal category verbal fluency. We used cluster analysis with collocation ratios between animal names seen in verbal fluency tasks as parameters. The purpose of study 2 was to verify the consistency between clusters seen during animal category verbal fluency and semantic similarity. We carried out a semantic similarity decision task of animal names and analyzed the scores with cluster analysis techniques. We compared the results with the results obtained in study 1 . The purpose of study 3 was to examine the characteristics of our qualitative analysis method. We used principal component analysis on the collocation ratios obtained in study 1 and semantic similarity scores obtained in study 2 and compared the results. The results of
\end{abstract}

臨床福祉専門学校言語聴覚療法学科 ${ }^{1)}$ ：干135-0043 東京都江東区塩浜 2-22-10

横浜新都市脳神経外科病院リハビリテーションセンター2)：テ225-0013 横浜市青葉区荏田町 433 番地

横浜市立大学大学院医学研究科精神医学部門 ${ }^{3)}$ : ₹ 236-0004 横浜市金沢区福浦 3-9

${ }^{11}$ Department of Speech Language Hearing Therapy, Clinical Welfare College: 2-22-10 Shiohama, Koto-ku, Tokyo 135-0043, Japan

${ }^{2}$ Rehabilitation Center, Yokohama Shintoshi Neurosurgery Hospital: 433 Edacho, Aoba-ku, Yokohama, Kanagawa 225-0013, Japan ${ }^{3}$ Department of Psychiatry, Graduate School of Medicine, Yokohama City University: 3-9 Fukuura, Kanazawa-ku, Yokohama, Kanagawa 236-0004, Japan 2013 年 4 月 3 日受稿 2013 年 11 月 1 日受理 
studies 1, 2 and 3 indicate that during animal category verbal fluency tasks in normal Japanese adults, clusters such as pets, wild cats, wild large herbivorous animals, Chinese astrology animals, Japanese countryside animals, primates and marine mammals can be observed. In addition, various semantic attributes can be examined by our analysis method.

Key words: verbal fluency tasks, qualitative analysis, collocation, triad rating, semantic similarity

\section{はじめに}

語想起課題（または語流暢性課題，以下VFT）は 前頭葉機能や言語機能に対する神経心理学的検査の一 つであり，伝統的には想起された単語数をもって評価 対象とする1)。近年，欧米ではVFTの結果表出され た語に注目した質的分析方法も提案されている. VFT の質的分析方法には表出された語のまとまり（同 一カテゴリーに属する言葉が連続して表出されるこ と）や切り替え（カテゴリーが異なる言葉へ切り替わ ること）に注目した分析方法 ${ }^{2}$ や，語順を解析・可視 化する方法 ${ }^{3-6)}$ がある。これら先行研究によると, VFT 結果は対象者の意味記憶の構造を反映している ため, VFTの質的分析は脳機能局在診断や疾患の鑑 別に有用であると報告されている2-6).

しかし，日本においてはVFTの質的分析について ほとんど報告されていない．日本の神経心理学的検査 場面で VFT の質的分析方法を行う際には，日本語話 者のVFT の質的分析の標準データの作成が必要であ る、ただし，先行研究で提案されているVFTの質的 分析方法をそのまま日本語話者に応用することについ てはVFTの言語や文化の差の影響が指摘されてお り7), 問題があると考える.

VFTの結果表出された語のまとまりや切り替えに よる質的分析方法には Troyer ${ }^{2)}$ の研究がある. Troyer は健常者の語のまとまり (cluster)，切り替え (switch) の標準データについて報告した。ただし， 彼女は基準となるカテゴリーをあらかじめ操作的に決 めて扮り, 表出された語の推移を報告したのみであっ た. 問題点としては彼女の操作的に決めたカテゴリー は欧米文化が反映されているため，日本語話者には応 用できないことが考えられる。

VFT の結果表出された語順を解析・可視化する分 析方法としてはChan $5^{3,4)}$ の研究とSchwarz ら ${ }^{5,6)}$ の研究がある. Chan $ら^{3,4)}$ はアルツハイマー病患者, ハンチントン病患者, 健常者のそれぞれのVFT 結果 を可視化し 3 群を比較した。彼女らは可視化するため
にVFTにより表出された語に独自の重みづけを用い た計算式を当てはめ数值化した。ただし，比較実験の ため分析対象語は， 3 群に共通したものであり，かつ 彼女らが分析しやすい意味的属性をもつ 12 語のみに 限定されている。よって, 問題点としては意味的な属 性の異なる対象語が増えた場合の妥当性は検証されて いないことが考えられる。また Schwartz ら ${ }^{5,6)}$ は左 右前頭葉損傷者と健常者を対象とし, 発話者と表出さ れた語の相関関係の散布図から質的な違いについて報 告した。ただし，彼女らの研究には十分な単語数を想 起できる対象者が必要であり，かつ対象語は 25 語と 少ない. 問題点としては彼女らの分析方法は表出語数 が多い対象者を選定する必要があることが考えられ る.

そこで，今回われわれは日本語話者にも応用可能な VFTの質的分析方法を提案することを目的とした. われわれの分析方法を考案する際，上記先行研究での 問題点を解決することを条件とした，条件としては， カテゴリーを操作的に決めない, 単純な実験操作で行 えること, 対象語が多いこと, 対象者の選定が想起数 に依存しないこととした，本条件に基づき，VFTで 表出される語の共起比率を変数とする分析方法の開発 および妥当性と特徵を確認するために 3 つの研究を用 いて検討した。

研究 1 ではVFT 結果の語の時間的な想起間隔に注 目し，VFT遂行中において短い想起間隔のうちにま とまって共起する語間の共起比率を算出した.ささらに, 得られた共起比率を基にクラスター分析を行い, VFT 遂行中の“まとまり”の特徵を可視化して捉え られるかどうかを検討した。

研究 2 ではわれわれの分析方法と意味的類似性判断 課題との整合性の検証を目的とした，研究 1 のFT 結果に抢いて頻度の高い 10 動物名について, 意味的 類似性判断課題を 3 つ組み法8)によって行った。 VFT の結果表出された語同士の共起比率と意味的類 似性判断課題それぞれのクラスター分析の結果の比較 から，われわれの提案する分析方法で得られた結果が 
意味的類似性判断の結果と類似していた.

研究 3 では対象者の意味記憶の構造を推定するうえ で，われわれの分析方法によって得られた結果がもつ 特徽について検討したＶVFT 結果での高頻度上位 10 動物名について語の共起比率と 3 つ組法による意味的 類似性判断の結果をそれぞれ主成分分析し，どのよう な意味的属性がそれぞれの課題で抽出されるか検討 し，われわれの提案する分析方法が多くの属性を抽出 できるのかについて検討した。

\section{研究 $1 ：$ VFT 遂行中に表出される語の 共起比率の算出}

\section{1. 対象}

関東在住の日本語を母語とする一般成人 109 人（男 性 56 名, 女性 53 名, 平均年齢 $27.3 \pm 5.0$ 歳)。2007 2008 年にかけて, 著者らの関係職場の知人や在住地 域の一般成人に対し口頭掞よび書面にて研究説明を行 い，同意が得られた者を対象とした。

\section{2. 手続き}

対象者の同意の下に 1 分間の動物カテゴリーVFT を個別の面接形式で施行した，施行された動物カテゴ リーVFT 結果から，想起された語，想起された語と 語の間の時間（想起間隔）を書き起こした.

\section{3 . 分析}

最低 20 人が挙げた上位 40 語を分析対象とした。想 起間隔は平均値, 標準偏差, 中央值, 四分位を算出し た.VFTでは後半になるにつれて想起間隔が延長し, 平均想起間隔がばらつく傾向が見られたため, 本研究 では第 1 四分位 0.362 秒と第 3 四分位 2.343 秒の間の 任意の秒数である 1 秒で区切ることとした，想起間隔 1 秒以内に連続表出された動物名をお互いに共起関係 がありとして，動物ペアごとの共起頻度を抽出した．

次に, 多く想起された動物名であれば他の動物名と の共起頻度も多くなることに考慮し, 得られた動物ぺ アの共起頻度はおのおのの動物名の総出現頻度数で割 ることで共起比率を求めた。

さらに上位 40 語について算出された共起比率をお の抢のの動物対の変数として行列に整理し, ウォード 法にてユークリッド距離を求めクラスター分析を行っ た。

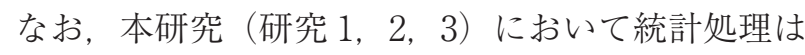
R（version 2.15.2）を用いた。

\section{4. 結果}

得られた共起比率の一部を表 1 で示した。 また上位 40 語での共起比率のクラスター分析の結果を図 1 に
示す。図 1 のクラスター分析図において距離が近い動 物名同士は，VFTではまとまって表出されやすいこ とを意味する。たとえばイヌ・ネコ間の距離は近く描 出された，他にも「キッネ・タヌキ」「イルカ・クジラ」 「オランウータン・チンパンジー・ゴリラ」「パンダ・ コアラ・ラッコ」「サル・トリ・ウマ・ウシ」などの ペアやまとまりのクラスターもいくつか描出された.

\section{研究 2：VFT 遂行中に表出される語の 共起比率と意味的類似性との関係}

\section{1. 対象}

関東在住の日本語を母語とする一般成人 68 人（男 性 24 名, 女性 44 名, 平均年齢 $29.2 \pm 7.8$ ). 全員の最 終学歴は大学拉よび大学院であった．2009２010 年 にかけて, 著者らの関係職場の知人や学生に対し口頭 および書面にて研究説明を行い，同意が得られた者を 対象とした。

\section{2. 手続き}

研究 1 に扔いてVFT の結果表出された高頻度上位 10 動物名（イヌ，ネコ, サル, キリン, ライオン, ゾウ, トラ, ウサギ, ウマ, ヒッジ) についてすべて の組み合わせ $10 \mathrm{C} 3=120$ 通りの 3 つ組みが仮名文字 で表記されたテストを紙面にて作成し，次のような教

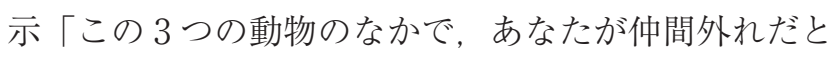
思うものを選んでください」で，3つの動物名から相 対的に仲間外れだと思われる 1 つの動物名を強制的に 選択させた。テストは集団で実施し，所要時間は約 15 分であった。

\section{3 . 分析}

全 120 問を通して，3つの動物名のなかから選ばれ た 1 つの動物名以外の残りの 2 つの動物名の組の選択 数を動物ペア $(10 \mathrm{C} 2=45$ 動物ペア）ごとに集計した。 集計された選択数は対象者数で割り, 平均選択数を求 めた. 平均選択数はおのおのの動物ペアの変数として 行列に整理し, ウォード法にてユークリッド距離を求 めクラスター分析を行った。

\section{4. 結果}

VFT 結果での共起比率によるクラスター分析図 (研 究 1) と意味的類似性判断のクラスター分析図 (研究 2) の結果を並べて図 2 に示した。両クラスター分析図と もに「イヌ・ネコ」「ライオン・トラ」「ゾウ・キリン」 「ウマ・ヒッジ」「サル・ウサギ」のペアが形成される 共通点が見られた。 
表 1 「動物」意味カテゴリー語想起課題中に表出された語の共起比率 (一部)

\begin{tabular}{llllllll}
\hline & イヌ & ネコ & サル & キリン & ライオン & ゾウ & トラ \\
\hline イヌ & 1 & - & - & - & - & - & - \\
ネコ & 0.7983 & 1 & - & - & - & - & - \\
サル & 0.2256 & 0.1939 & 1 & - & - & - & - \\
キリン & 0.1086 & 0.1243 & 0.0994 & 1 & - & - & - \\
ライオン & 0.1235 & 0.1472 & 0.0610 & 0.1761 & 1 & - & - \\
ゾウ & 0.1341 & 0.1375 & 0.0764 & 0.4336 & 0.1357 & 1 & - \\
トラ & 0.1078 & 0.1037 & 0.0566 & 0.1181 & 0.3504 & 0.1168 & 1 \\
ウサギ & 0.1218 & 0.1032 & 0.0464 & 0.0863 & 0.0725 & 0.1000 & 0.0758 \\
ウマ & 0.1391 & 0.1200 & 0.0993 & 0.0803 & 0.0662 & 0.0687 & 0.0611 \\
ヒッジ & 0.1389 & 0.0959 & 0.1136 & 0.0294 & 0.0224 & 0.0394 & 0.0480 \\
トリ & 0.1319 & 0.0966 & 0.1870 & 0.0373 & 0.0226 & 0.0234 & 0.0078 \\
クマ & 0.0596 & 0.0612 & 0.0214 & 0.0303 & 0.0640 & 0.0240 & 0.0410 \\
ウシ & 0.0828 & 0.0851 & 0.0769 & 0.0231 & 0.0400 & 0.0331 & 0.0508 \\
カバ & 0.0694 & 0.0714 & 0.0538 & 0.1712 & 0.0672 & 0.1402 & 0.0254 \\
ゴリラ & 0.0336 & 0.0417 & 0.1048 & 0.0484 & 0.0672 & 0.0427 & 0.0431 \\
ネズミ & 0.0405 & 0.0345 & 0.0148 & 0.0078 & 0.0000 & 0.0083 & 0.0254 \\
パンダ & 0.0405 & 0.0345 & 0.0538 & 0.0236 & 0.0160 & 0.0517 & 0.0254 \\
タヌキ & 0.0629 & 0.0647 & 0.0385 & 0.0323 & 0.0081 & 0.0169 & 0.0000 \\
\hline
\end{tabular}

語想起課題中の語と語の想起間隔 1 秒以内に連続表出された動物名をお互い に共起関係がありとした。

共起比率は動物ペアの共起頻度を動物ペアの総出現頻度数で割ることで算出 した。たとえば, イヌとネコは 109 人の語想起データ中 95 回共起し, イヌ とネコの出現頻度はそれぞれ 109 回と 105 回であった。求める共起比率は 95/ $(109+105-95)=0.7983 \cdots$ となる.

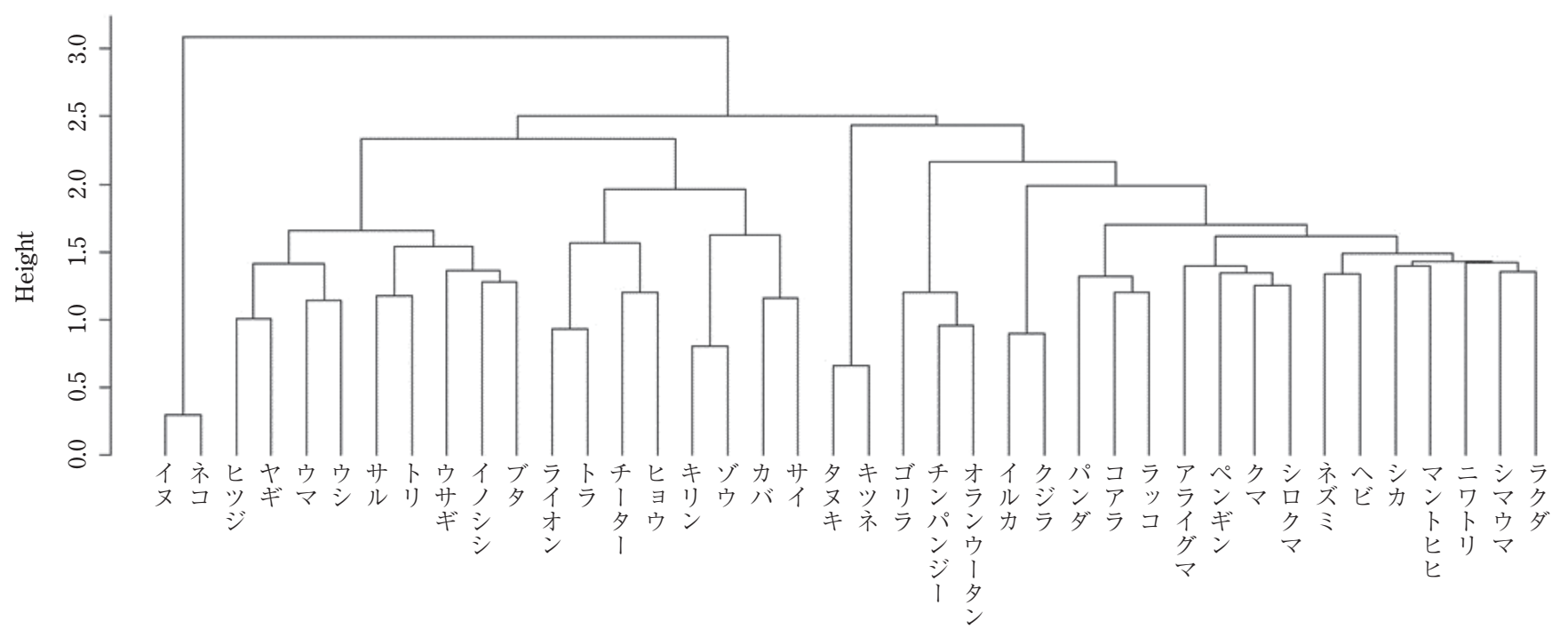

図 1 動物カテゴリー語想起課題上位 40 語の共起比率によるクラスター分析

\section{研究 3：VFT 遂行中に表出される語の 共起比率による質的分析の特徵}

\section{1 . 手続きと分析}

研究 1 で求められたVFTの結果表出された高頻度 上位 10 動物名についての共起比率と研究 2 で求めら れた 10 動物名についての 3 つ組法による意味的類似 性判断から得られた平均選択数の相関関係をスピアマ
ン順位相関係数検定によって求めた.

さらに研究 1 で求められた共起比率と研究 2 で求め られた意味的類似性判断での平均選択数をそれぞれ主 成分分析し，比較した。主成分分析では，累積寄与率 $80 \%$ までの上位成分の寄与率，各因子の上位 3 語と下 位 3 語を求めた。

\section{2. 結果}

研究 1 で求められた上位 10 動物名についての共起 


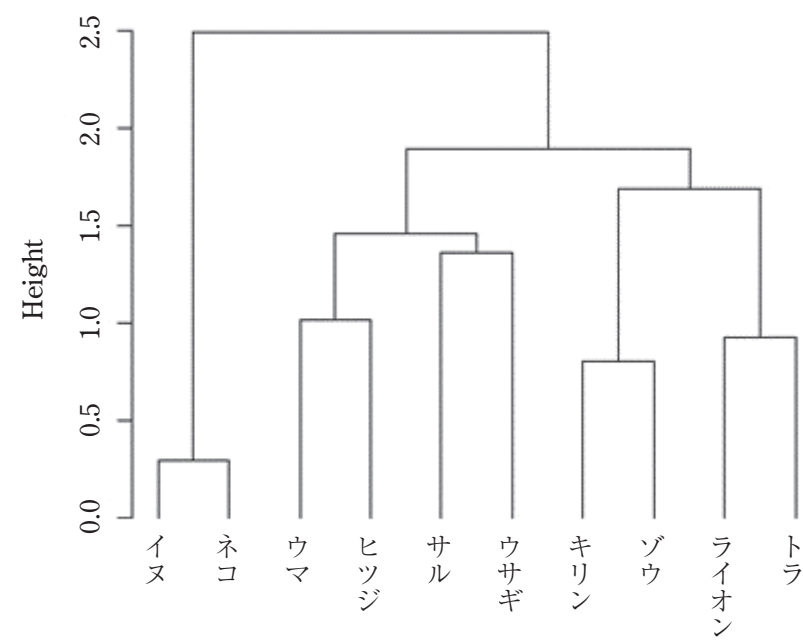

語想起課題での共起比率

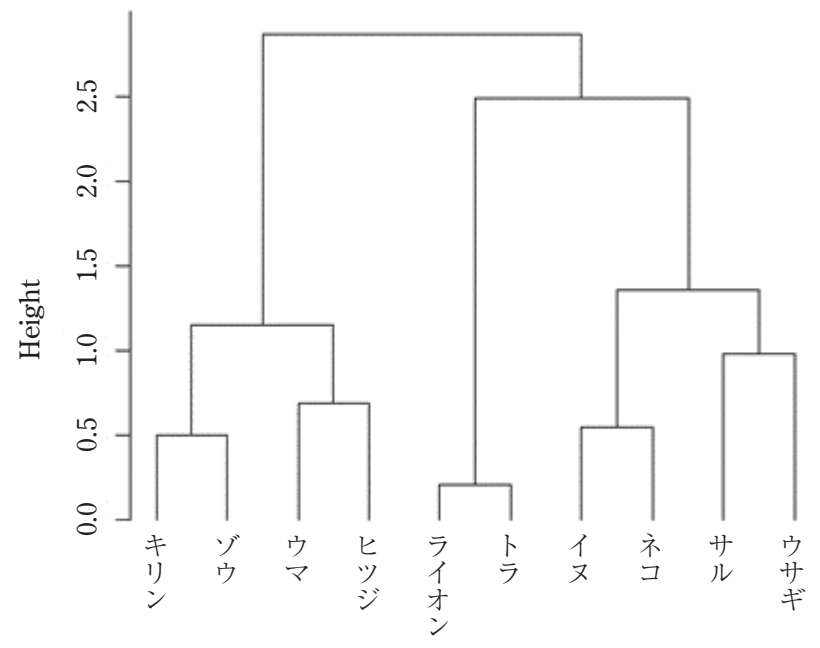

意味的類似性判断での平均選択数

図 2 動物カテゴリー語想起課題上位 10 語の共起比率のク ラスター分析（上）および同 10 動物名の意味的類似 度判断のクラスター分析 (下)

比率と研究 2 で求められた意味的類似性判断での平均 選択数の間には弱い相関（ $\mathrm{r}=0.24, \mathrm{p}<0.05 ）$ が認め られた。

VFT での共起比率による主成分分析（研究 1）と 意味的類似性判断の主成分分析（研究 2）の結果を並 べて表 2 に示した.VFTでの共起比率の主成分分析 の結果, 第 5 主成分までの累積寄与率は 83\%であった。 第 1 主成分は「ペット」対「野生」第 2 主成分は「大 型動物」対「牧場動物」, 第 3 成分は「大型草食」対「肉 食」, 第 4 主成分は「ウサギ以外の動物」対「ウサギ」, 第 5 主成分は「サル以外の動物」対「サル」となった。 一方で，意味的類似性判断の主成分分析の結果，第 3 主成分までの累積寄与率は $88 \%$ となった。第 1 主成 分は「ペット」対「大型草食」，第 2 主成分は「肉食」
対「草食」,第 3 主成分は「サル」対「サル以外の動物」 となった。

\section{考察}

VFT 結果の質的分析は対象者の意味記憶の構造の 推定を行ううえでは有用な方法の一つとされ，欧米に おいてはいくつか分析方法が提案されている.ただし, 日本語話者に応用することについては問題があると考 えられる。 そこで本研究ではカテゴリーを操作的に決 めない，単純な実験操作で行えること，対象語が多い こと, 対象者の選定が想起数に依存しない分析方法を 提案した，われわれの分析法に必要な変数はVFTで の想起間隔のみであり，カテゴリーに対する操作は排 除した，実験操作は一定間隔での共起比率を算出する ことですみ, 複雑な操作は必要としない. 本研究では, 20 名以上が想起した上位高頻度語 40 語を対象語とし た．対象者は一切の選定は行わず，一般成人とした． われわれの提案する分析方法の妥当性および特徽を示 すためにいくつかの検討を行った.

\section{1 .「動物」意味カテゴリー語想起課題から“まと まり”を抽出する}

VFT 遂行中において短い想起間隔のうちにまと まって共起する語間の共起比率を算出し, クラスター 分析を行った結果,「ペット」「野生肉食獣」「野生大 型草食獣」「干支」「里山動物」「サル科動物」「海洋哺 乳類」などと思われるペアやまとまりが描出された。 カテゴリーに主観的な操作を加えることなく, 共起比 率から VFT 遂行中の“まとまり”の特徽を捉えられ ることを示した。

\section{2.“まとまり”と意味的類似性判断との共通点}

VFT の結果表出された高頻度上位 10 動物名におけ る共起比率と 3 つ組法での意味的類似性判断の平均選 択数のクラスター分析図の比較では動物ペアの形成は 共通であった。って，われわれの方法によって VFTでまとまって表出されやすい語が抽出され，さ らにそれらが意味的に類似していることが確認され た。しかし、「ウマ・ヒッジ」ペアが VFT 遂行中に は「干支」関連である「サル・ウサギ」ペアとまとま りを形成し，3つ組法による意味的類似性判断課題で は「草食動物」である「キリン・ゾウ」ペアとまとま りを形成した，日本人の動物意味カテゴリーVFTで は日本語特有の系列的要素の強い「干支」カテゴリー が関与する可能性が示唆された。

\section{3 .“まとまり”と意味的類似性判断との相違点}

VFT 結果の上位 10 語に扮ける共起比率と 3 つ組法 
表 2 動物カテゴリー語想起課題上位 10 語の共起比率の主成分分析結果(上) および同 10 動物名の意味的類似性判断の主成分分析結果（下）

語想起での共起比率の主成分分析

\begin{tabular}{cc}
\hline \multicolumn{2}{c}{ 第 1 主成分 } \\
\hline 寄与率 (累積) $26.54 \%(26.54 \%)$ \\
\multicolumn{2}{c}{$\lceil$ ヘヘット」対「野生」 } \\
\hline 順位 & 動物名 (主成分得点) \\
\hline 1 位 イヌ & 0.6161 \\
2 位 ネコ & 0.6056 \\
3 位 サル & 0.1877 \\
\hline 8 位 トラ & -0.2178 \\
9 位 ゾウ & -0.2281 \\
10 位 キリン & -0.2596 \\
\hline \multicolumn{2}{|c}{} \\
\hline
\end{tabular}

\begin{tabular}{cr}
\hline \multicolumn{3}{c}{ 第 4 主成分 } \\
\hline \multicolumn{2}{c}{ 寄与率 (累積) $11.74 \%(74.02 \%)$} \\
\multicolumn{2}{r}{ 「ウギ以外」対「ウサギ」 } \\
\hline 順位 & 動物名 (主成分得点) \\
\hline 1 位 ウマ & 0.2486 \\
2 位 ヒツジ & 0.1904 \\
3 位 キリン & 0.1835 \\
\hline 8 位 ネコ & 0.0474 \\
9 位 イヌ & 0.0341 \\
10 位 ウサギ & -0.8881 \\
\hline
\end{tabular}

\begin{tabular}{cc}
\hline \multicolumn{3}{c}{ 第 2 主成分 } \\
\hline \multicolumn{2}{c}{ 寄与率 (累積) $20.19 \%(46.74 \%)$} \\
\multicolumn{2}{c}{ 「大型動物」対「牧場動物」 } \\
\hline 順位 & 動物名 $($ 主成分得点) \\
\hline 1 位 ゾウ & 0.3351 \\
2 位 キリン & 0.3332 \\
3 位 ネコ & 0.2955 \\
\hline 8 位 サル & -0.0807 \\
9 位 ウマ & -0.4631 \\
10 位 ヒツジ & -0.5421 \\
\hline \multicolumn{3}{c}{} \\
\hline
\end{tabular}

第 5 主成分

寄与率 (累積) $10.05 \%$ (84.08\%)

「サル以外」対「サル」

\begin{tabular}{rlr}
\hline 順位 & \multicolumn{1}{c}{ 動物名 $($ 主成分得点) } \\
\hline 1 位 & ウマ & 0.3124 \\
2 位 & ネコ & 0.1806 \\
3 位 & ヒッジ & 0.1797 \\
\hline 8 位 & ライオン & 0.0469 \\
9 位 & トラ & 0.0166 \\
10 位 & サル & -0.8834 \\
\hline
\end{tabular}

意味的類似性判断での平均選択数の主成分分析

\begin{tabular}{|c|c|c|}
\hline \multicolumn{3}{|c|}{ 第 1 主成分 } \\
\hline \multirow{2}{*}{\multicolumn{3}{|c|}{$\begin{array}{c}\text { 寄与率 (累積) 43.54\% (43.54\%) } \\
\lceil ヘ ゚ ッ ト 」 \text { 対「大型草食」 }\end{array}$}} \\
\hline & & \\
\hline 順位 & 動物名 & （主成分得点） \\
\hline 1 位 & ネコ & 0.4829 \\
\hline 2 位 & イヌ & 0.4163 \\
\hline 3 位 & ウサギ & 0.2104 \\
\hline 8 位 & ウマ & -0.3553 \\
\hline 9 位 & ゾウ & -0.4125 \\
\hline 10 位 & キリン & -0.4580 \\
\hline
\end{tabular}

\begin{tabular}{cc}
\hline \multicolumn{2}{c}{ 第 2 主成分 } \\
\hline \begin{tabular}{c} 
寄与率 (累積) $35.99 \%(79.53 \%)$ \\
\multicolumn{2}{c}{ 「肉食」対「草食」 }
\end{tabular} \\
\hline 順位 & 動物名（主成分得点） \\
\hline 1 位 トラ & 0.5613 \\
2 位 ライオン & 0.5586 \\
3 位 ネコ & 0.1495 \\
\hline 8 位 サル & -0.2179 \\
9 位 ヒツジ & -0.3243 \\
10 位 ウサギ & -0.3709 \\
\hline
\end{tabular}

\begin{tabular}{ccc}
\hline \multicolumn{3}{c}{ 第 3 主成分 } \\
\hline 寄与率 (累積) $15.53 \%(62.27 \%)$ \\
\multicolumn{2}{c}{ 「大型草食」対「肉食」 } \\
\hline 順位 & 動物名 $($ 主成分得点) \\
\hline 1 位 ゾウ & 0.4811 \\
2 位 キリン & 0.4488 \\
3 位 ウマ & 0.0606 \\
\hline 8 位 ネコ & -0.0174 \\
9 位 ライオン & -0.4886 \\
10 位 トラ & -0.5592 \\
\hline
\end{tabular}

\begin{tabular}{|c|c|c|}
\hline \multicolumn{3}{|c|}{ 第 3 主成分 } \\
\hline \multirow{2}{*}{\multicolumn{3}{|c|}{$\begin{array}{c}\text { 寄与率 (累積) } 9.20 \% \text { (88.74\%) } \\
\lceil サ ル 」 \text { 対「サル以外」 }\end{array}$}} \\
\hline & & \\
\hline 順位 & 動物名（ & 戎分得点) \\
\hline 1 位 & サル & 0.7809 \\
\hline 2 位 & トラ & -0.0160 \\
\hline 3 位 & ライオン & -0.0320 \\
\hline 8 位 & ウサギ & -0.2631 \\
\hline 9 位 & イヌ & -0.2856 \\
\hline 10 位 & ヒツジ & -0.3867 \\
\hline
\end{tabular}

での意味的類似性判断の平均選択数との間には弱い相 関が見られた。これは両課題では異なる意味的属性の 関与が示唆されるため弱い相関結果となったと考えら れる，そこで, VFTでの共起比率と 3 つ組法での意 味的類似性判断に扔いて抽出される意味的な属性には どのような違いがあるかをおのおのの課題の主成分分 析で検討した．３つ組法による意味的類似性判断課題 では, 動物の「大小」や「肉食・草食」の属性が抽出 された，一方で, 動物意味カテゴリーVFTの共起比 率からは「肉食·草食」の属性に加え,「ペット」か「牧 場動物」か「野生動物」の属性も抽出できた。よって, VFT での語の共起比率による分析法で抽出される意
味的属性は，3つ組法による意味的類似性判断課題で 抽出される意味的属性と一部は重複した。ただし, VFT での語の共起比率による分析法のほうがより多 くの意味的属性が抽出されるため両課題の相関関係が 弱いものと解釈された。 上記の考察 $1,2,3$ より, わ れわれが提案するVFT 結果の質的分析方法は, 確立 されている意味的類似性判断課題よりも多くの意味的 属性を抽出することが可能であることが示唆された.

\section{4. 今後の課題, 臨床応用}

今後の課題は標準デー夕の作成および臨床応用であ る，標準データを作成するうえでは，想定する障害群 に合わせた年齢別のデータを分析する必要がある，例 
として成人失語症者群や変性疾患群に対応するデー夕 を作成する場合, 60 歳以降の健常者の分析が必要で ある，今後は目的に応じた対象者の選定を行い，年齢 別のデー夕を作成していく予定である.

また，臨床応用としてはVFTの質的分析から対象 者の意味記憶の構造の推定を行い, 脳機能局在診断, 疾患の鑑別が考えられる. 先行研究 ${ }^{3-6)}$ が示唆するよ うに疾患別，病巣別に異なる意味的属性が抽出される 可能性はある。われわれの分析方法でも同様な鑑別結 果が再現できるよう疾患別, 病巣別にも応用していき たい。

謝辞 デー夕収集に際し, ご協力いただいた病院や施設の職 員・関係者の皆様, 臨床福祉専門学校の学生㧍よび教員の皆様, 鹿島アントラーズ・大宮アルディージャサポーターの皆様に厚 く御礼申し上げます。

\section{文献}

1) Lezak MD, Howieson DB, Loring DW, et al: Neuropsychological Assessment, 4th ed, Oxford University Press, New York, pp 518-522, 2004.

2) Troyer AK: Normative data for clustering and switching on verbal fluency tasks. J Clin Exp Neuropsychol, 22:
370-378, 2000.

3) Chan AS, Butters N, Paulsen JS, et al: An assessment of the semantic network in patients with Alzheimer's disease. J Cogn Neurosci, 5: 254-261, 1993.

4) Chan AS, Butters N, Paulsen JS, et al: Comparison of the semantic networks in patients with dementia and amnesia. Neuropsychology, 9: 177-186, 1995.

5) Schwartz S and Baldo J: Distinct patterns of word retrieval in right and left frontal lobe patients: a multidimensional perspective. Neuropsychologia, 39: 1209-1217, 2001.

6) Schwartz S, Baldo J, Graves RE, et al: Pervasive influence of semantics in letter and category fluency: a multidimensional approach. Brain Lang, 87: 400-411, 2003.

7) Kempler D, Teng EL, Dick M, et al: The effects of age, education, and ethnicity on verbal fluency. J Int Neuropsychol Soc, 4: 531-538, 1998.

8) Henley NH: A psychological study of the semantics of animal terms. J Verbal Learning Verbal Behav, 8: 176184,1969

別刷請求先： $=135-0043$ 東京都江東区塩浜 2-22-10 臨床福祉専門学校言語聴覚療法学科 浜田智哉 